\title{
エッジ励起高出カマイクロチップレーザー用水冷ヒートシンクの開発
}

\author{
常包 正樹 1,2 , 平等 拓範 2 \\ ${ }^{1}$ (財)ふくい産業支援センター 産業技術研究センター（†910-0102 福井市川合熟塚町61字北稲田10) \\ 2自然科学研究機構 分子科学研究所分子制御レーザー開発研究センター \\ （ \%444-8585 愛知県岡崎市明大寺町字西郷中38）
}

\section{Efficient, Water-Cooled Heat Sink for High-Power Edge-Pumped Microchip Lasers}

\author{
Masaki TSUNEKANE ${ }^{1,2}$ and Takunori TAIRA ${ }^{2}$ \\ ${ }^{1}$ Fukui Industrial Support Center 61-10 Kawaiwashizuka, Fukui 910-0102 \\ ${ }^{2}$ National Institutes of Natural Sciences, Institute for Molecular Science, Laser Research Center for Molecular Science, \\ 38 Nishigo-Naka, Myodaiji, Okazaki, Aichi 444-8585
}

(Received September 13, 2005)

\begin{abstract}
An efficient, compact water-cooled heat sink has been developed for high-power edge-pumped microchip lasers. A vertical, water jet impingement cooling system can reduce the heat sink cross-sectional area to $\varnothing 10$ $\mathrm{mm}$. Experimental results and theoretical analysis show dramatic enhancement of the heat transfer rate by a microchannel structure on the water-impinged, behind the heat sink top where laser material is bonded. Thermal resistance of $0.25^{\circ} \mathrm{C} / \mathrm{W}$ was achieved in the central $\varnothing 5 \mathrm{~mm}$ area of the heat sink's cooling surface. Continuous-wave (CW) laser output over $300 \mathrm{~W}$ was successfully obtained from the diode edge-pumped, $\mathrm{Yb}$ :YAG microchip core $(\varnothing 5 \mathrm{~mm}$ area $0.3 \mathrm{~mm}$ thick) bonded on the new heat sink.
\end{abstract}

Key Words: Heat-sink, Jet impingement, Microchannel, Microchip, Yb:YAG

\section{1.はじめに}

福井県には，伝統的に金属工作加工機械，眼鏡枠，表 面処理, 繊維, 化学, プラスチックなどの材料創成・加 工産業が発達しているが，これらの産業が保有する技術 を基盤にさらに新技術創出を図ることを目的として，平 成12年から 5 年間の計画で文部科学省から地域結集型共同 研究事業の指定を受け「光ビームによる機能性材料加工創 成技術開発」を研究テーマに，産学官での共同研究を行っ ている，その中では高輝度光ビームを発生する新しい光 源開発として特にYb:YAG固体レーザー媒質の有する可能 性と実用性の高さに注目し, 高出力のCWおよび超短パル スレーザー装置の開発を進めている。本報告ではマイク ロチップレーザー1)のスケーラブルな発展型として著者ら が取り組んでいるユニークな高出力エッジ励起Yb:YAGマ イクロチップレーザー2)に不可欠な高性能小型水冷ヒート シンクの試作とその冷却性能評価, 設計の最適化につい て, 実験と計算の両面から検討した結果について述べる.

\section{2. エッジ励起Yb:YAGマイクロチップレーザーの特長}

\section{$2.1 \mathrm{Yb}: Y A G の$ 特長}

Yb:YAGはInGaAs系半導体レーザー (Laser Diode以下LD と記す)において励起可能な $940 \mathrm{~nm}$ と $970 \mathrm{~nm}$ 帯に吸収域を
持ち $1030 \mathrm{~nm}$ のレーザー光を発生する固体レーザー媒質で ある。励起光波長とレーザー発振光波長が近いことか ら，エネルギー差として媒質内で発生する発熱の割合も 吸収エネルギーの9\%(940 nm励起の場合)に抑えられ，同 じ母材で既に広く普及している808 nm励起のNd:YAGの発 熱量の半分以下であるため, 高出力動作時にも熱による レーザービームへの影響，いわゆるビーム品質の劣化の 少ない固体レーザー媒質として近年急速に期待が高まっ ている ${ }^{3,4)}$. 加えて励起光の吸収許容波長幅がNd:YAGの15 倍広いため(波長半值幅 $18 \mathrm{~nm}$ ), LDの波長の変動による レーザー出力の変動が小さいこと，Ybを高濃度添加して もレーザー特性の劣化が少なく, このため薄い媒質内で も励起光を十分吸収させることができる。またもう一つ ユニークなYb:YAGの特長として, 発光のスペクトル幅が $8.5 \mathrm{~nm}$ と広いために，同じ媒質でCWのみならずピコから フェムト秒までの超短パルス発生も可能であるという点 があげられる

このようにYb:YAGは多くの優れた特長を有するが，一 方で室温において既にレーザー下準位に電子が存在する 準四準位系材料であるためレーザー光の自己吸収があ り，また誘導放出断面積が小さいためにレーザー発振を 起こさせるために必要な励起光の強度 (しきい值密度)が $\mathrm{Nd}: \mathrm{YAG}$ に比べ高い欠点がある。さらに環境温度に比較的 敏感で高温になるほどレーザー特性が大きく劣化するこ 
とも実用上問題である。このような欠点をできるだけ抑 え，先ほど述べた Yb:YAGの特長を最大限に生かす媒質形 状がアクティブミラー7)であり, 励起も含めた構成の典型 例に薄ディスクレーザー8,9) とエッジ励起マイクロチップ10) があげられる。

\section{2 エッジ励起コンポジットYb:YAGマイクロチップ レーザーの構成と動作原理}

Fig. 1にエッジ励起マイクロチップレーザーの概念構造 を示す.コンポジットマイクロチップは中央のコアにYb: YAG，その周囲にレーザー発振元素を含まない透明なア ンドープYAGが一体形成されており，その片側一面を ヒートシンクに接合しレーザー媒質(コア)の冷却を行う。 レーザー共振器はマイクロチップのヒートシンクに接合 される面にあらかじめ形成されたレーザー光に対する全 反射膜と，その反対側のレーザー光に対して無反射膜の 形成された面を通して外部に設けた出力ミラーとの間で 構成される，基本的には薄ディスクレーザーなどのアク ティブミラーの発振・排熱構成と同一である.エッジか ら導入された励起光はアンドープYAGガイドおよびYb: YAG媒質中を全反射で伝搬し，コアのYb:YAG内を伝搬す る際に次第に吸収されレーザー光に変換される。この際 $\mathrm{Yb}$ 濃度を適切に設定することで径方向に $\mathrm{mm}$ オーダーある コアを1回通過する際にほとんどの励起光を吸収させるこ とが可能であるため，同軸励起型の薄ディスクレーザー のような多重反射励起のための複雑な光学系をレーザー 媒質の近傍に配置する必要がなく，簡便な構成で強靫な レーザーヘッドを構成することができる。またマイクロ チップのガイド周囲の励起光の導入方向を増やすことで コアを広げることなく高密度励起や高出力化が容易であ る点も大きな利点である. もちろんFig. 1(b)に示すように アクティブミラーの特徵としてコア内での等温面はヒー トシンクの面と平行に形成されレーザー光はこれと垂直 に透過するため，レーザー発振光内での波面の乱れが生 じにくく高輝度のレーザービームが得られやすい.

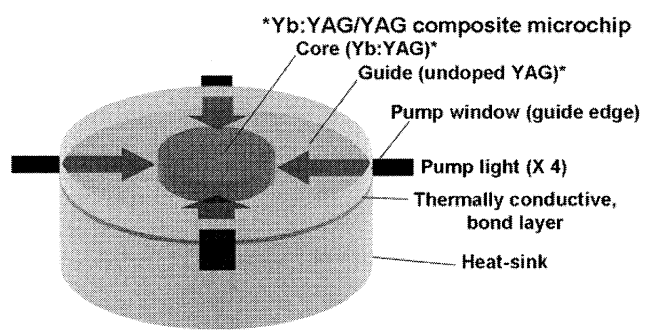

(a)

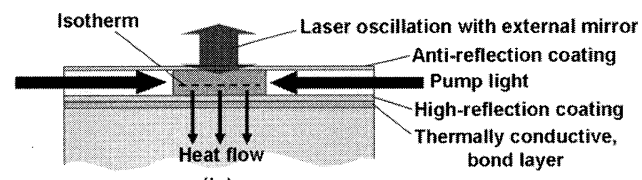

(b)

Fig. 1 Configuration of the diode edge-pumped, composite Yb:YAG/YAG microchip laser, a top (a) and a crosssectional view (b).

\section{3. 高性能小型ヒートシンク開発の必要性}

以上述べたように多くの優れた特長を有するエッジ励 起コンポジットYb:YAGマイクロチップレーザーにおい て，これまで著者らのグループでは300 W励起時にQCW 動作で135 W $\mathrm{W}^{11)}$ ，CW動作で最大90 W ${ }^{12)}$ を実証している. しかし加工用光源としてCW出力 $300 \mathrm{~W}$ 目指すために は, さらに3倍以上の高い $1 \mathrm{~kW}$ 程度の励起光を結晶内に導 入する必要がある. LDからのより多くの励起光を薄いマ イクロチップエッジに絞り达むためには焦点距離の極め て短い集光レンズ $(\mathrm{f}<10 \mathrm{~mm})$ を用いる必要があるが，そ の場合集光レンズはエッジから $3 \mathrm{~mm}$ 程度まで近接する配 置となり，しかも多方向から例えばコアの周囲4方向から 励起光を導入する場合, レンズがヒートシンクにぶつか らないためにはヒートシンクの断面積はマイクロチップ の外形(現行約 $\varnothing 10 \mathrm{~mm}$ ) とほほ同じかそれ以下にする必要 がある。さらに近接するレンズのサイズも考慮すると ヒートシンクはその断面積を維持したまま縦に $10 \mathrm{~mm}$ 以上 長いことが必要になる。従来我々のグループで開発した 水冷ヒートシンク ${ }^{11,12)}$ は冷却水をマイクロチップに対して 横に流す配置であったため, ヒートシンクの水の出入り 口2方向に大きな突起がありそのままでは突起のある2方 向からはレンズを近づけることができない, また単に結 晶取り付け部(金属部分)のみ長く伸ばした場合，結晶から 冷却水までの距離が著しく長くなり冷却効率が低下する ことが容易に予想される。 そこで今回, 新しく縦長形状 の水冷ヒートシンクを試作開発した。

新しいヒートシンクは形状を細く長くするために内部 の導水構造を従来のものから大幅に変更し, 縦長の円筒 状ヒートシンク内部に, 冷却水が流れる細長いパイプ(内 パイプ)を先端が結晶取り付け部の裏側近傍まで達するま で挿入し, その先端から冷却水が結晶取り付け部の裏側 に向けて吹き付ける構造とした。 冷却水はその後内パイ プの外側とヒートシンク内壁(外パイプ内側)の間を通って 外部に排出される。このような構造にすることで細長い ヒートシンク形状においても確実に冷却水を先端まで導 入することができ，ささらにヒートシンクの外形の長さが 変わっても結晶取り付け部近傍は変わらないために常に 安定して同じ泠却効率を得ることができる。また後述す るように水(噴流)がヒートシンク裏面に衝突することに よって従来の水を横に流す場合に比べ冷却効率の向上(水 とヒートシンクとの界面での熱伝達係数の向上) も期待さ れる。これと似た構造はドイツの薄ディスクレーザーで も例がみられるが13), 我々はさらなる冷却効率の向上を 目指し，水を吹き付ける結晶取り付け面の裏側にマイク ロチャンネルの凹凸を設けたヒートシンク (Vertical waterflow microchannel heat-sink: VFMH) を試作し14), その性能 を実験と理論設計の両面から評価，最適化した。なお， 噴流と冷却面の凹凸構造を組み合わせたものはLD用の ヒートシンクで既に適用された例15)があり，形状やサイ ズの違いはあれ冷却作用としては本稿のヒートシンクと 原理的に同じであると考えられる。しかしながら，本稿 のように詳細に且つ定量的に構造と冷却性能を評価した 
論文は著者が知る限り初めてである。また固体レーザー 結晶の冷却に適用した例も初めてであり, 本稿は今後 様々なヒートシンクの設計論を定量的に議論する上で有 意義な論文になると考えている。

\section{4. 新型ヒートシンクの冷却性能の実験評価}

\section{1 比較サンプルの構造}

高出力高性能固体レーザーの開発においては結晶の選 択や形状，励起方法などと同様に結晶を冷やすヒートシ ンクの冷却効率もレーザー性能を左右する非常に重要な ファクターである。我々は構造の最適化も含めてヒート シンクの冷却性能の客観的な評価を実験的に試みた. Fig. 2に比較のために試作した4種類の縦水流型ヒートシンク と従来の横水流型ヒートシンクの断面構造の模式図を示 す。それぞれ結晶取り付け面の裏面が平面のもの (a), 裏 面一面にサンドブラスト加工 $(\varnothing 100 \mu \mathrm{m}$ のガラスビーズを 高速エアで吹き付ける加工) を行い $100 \mu \mathrm{m}$ 程度のランダム な凹凸を付けたもの (b)，300 $\mu \mathrm{m}$ の幅で $600 \mu \mathrm{m}$ 間隔に深さ $0.5 \mathrm{~mm}$ の格子状の溝(マイクロチャンネル)をワイヤー放電 加工により形成したもの (c), さらに細かく $140 \mu \mathrm{m}$ 幅で

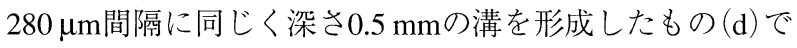
ある.なおヒートシンクの最外形(外パイプ)は $\varnothing 10 \mathrm{~mm}$ (Fig. 10参照)で高さは $25 \mathrm{~mm}$, 外パイプの内径は $\varnothing 8 \mathrm{~mm}$ ある.内パイプの内径は $\varnothing 2.6 \mathrm{~mm}$, 外径 $\varnothing 5 \mathrm{~mm}$ で内パイ

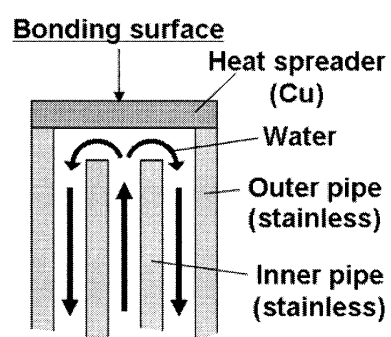

(a)

\section{Microchannel} $(300 \mu \mathrm{m})$

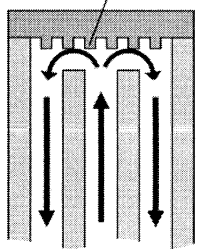

(c)

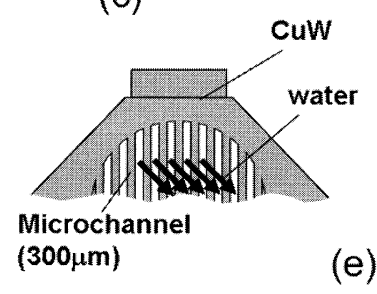

(e)

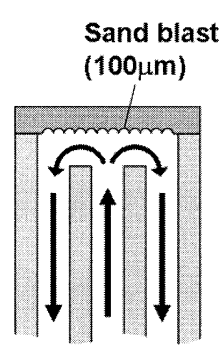

(b)

Microchannel $(140 \mu \mathrm{m})$

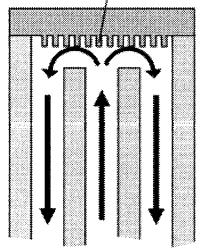

(d)

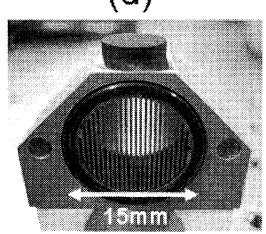

Fig. 2 Cross-sectional view of 4 types of the vertical water flow heat-sinks, a flat back (a), a sand blasted (b), a 300micron-width microchannel (c), a 140micronwidth microchannel (d), and a conventional transverse flow microchannel heat-sink with the photo (e).
プの先端とヒートシンク裏面のマイクロチャンネル凸部 (ない場合は平面部)との距離は $0.5 \mathrm{~mm}$ ですべて一定とし た. またヒートシンクの上面(結晶取り付け面) と裏側のマ イクロチャンネル凹部(ない場合は平面部) との距離(厚み) は0.5 mmである。(e) は従来のヒートシンクで溝幅は300 $\mu \mathrm{m}$, 間隔は $600 \mu \mathrm{m}$, マイクロチャンネルの長さは最大 15 $\mathrm{mm}$ である。新しい構造のヒートシンクの材料としては結 晶を取り付ける上部のヒートスプレッダーは銅 $(\mathrm{Cu})$, 本 体はステンレス (SUS304)で，電子ビーム溶接により接合

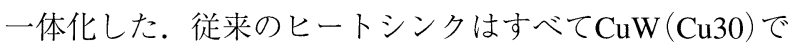
ある。なお，以下図中では (a)をFlat，(b)を SB，(c)を MC300，（d）をMC140，（e）をConvと表記する.

\section{2 冷却水の圧力損失}

水冷ヒートシンクの場合, 冷却効率が高くても水の圧 力損失が大きいと駆動に強力 (巨大)なポンプが必要になり 実用的でない. Fig. 3は製作したヒートシンクの水の流量 に対する圧力損失 (差圧)を測定した結果である．縦水流型 では裏面の処理にかかわらず2 L/min(リッター毎分)時に 約 $0.2 \mathrm{MPa}$ の損失を生じている。これは主にヒートシンク 内部で180度水路が折り返させる際に生じていると考えら れる. 励起用高出力半導体レーザーに使用されている水 冷ヒートシンクにおいても定格冷却水流量において $0.2 \mathrm{k}$ $0.5 \mathrm{MPa}$ が一般的であるため, 同じ冷却系を使用する上に おいてまったく問題ない圧力損失である。なお，従来の 横水流型では水の流れる断面積が大きく, 水路の折れ曲 がりも少ないため非常に低い圧力損失を示している。し かし流体を用いて高い冷却効率を得ようとする場合，内 径を細くして流速を上げる, 流体との放熱接触面積を増 やす, 流れの屈曲による衝突効果などで温度境界層を薄 くする等の方法が取られるが，これらはいずれも同時に 流体の粘性による摩擦損失を生じ圧力損失は上昇するた め，一般に圧力損失と冷却性能とは正の相関がある。し たがってあまり圧力損失が低いヒートシンクは逆にそれ らの作用が少ないとも考えられ, 冷却能力も同様に低い 可能性が疑われる。

\section{3 冷却性能の比較実験}

Fig. 4にヒートシンクの冷却能力を測定した実験系を示 す. 方法としてはヒートシンクの結晶取り付け面に所定

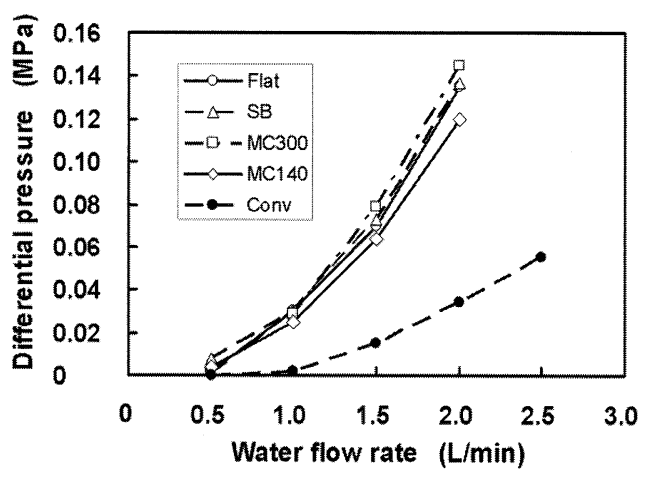

Fig. 3 Differential water pressure of the heat-sinks as a function of water flow rate. 


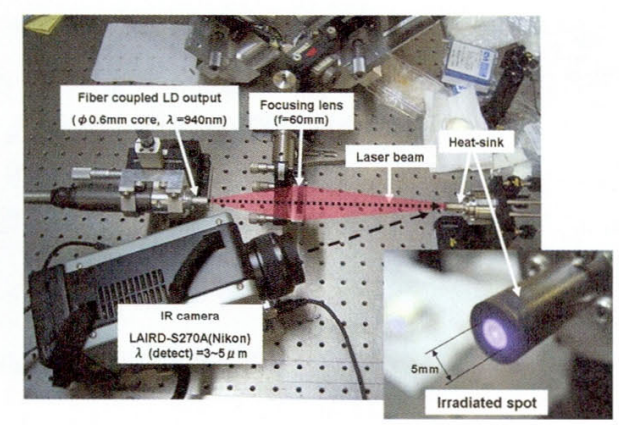

Fig. 4 Experimental setup for the measurement of the cooling efficiency of the heat-sinks.

の熱量を与え, その領域の温度上昇をIRカメラで非接触 に測定して冷却能力を評価した。熱源としてコア径 $\varnothing 0.6$ $\mathrm{mm}, \mathrm{NA} 0.2$ のファイバー出力型LDからのレーザー光(波 長940 nm) 焦点距離60 mmのレンズでヒートシンクの結 晶取り付け面に緩く集光し, 表面で吸収させて非接触に 発熱させた。ヒートシンク表面でのビーム径はØ5 mm で, 今回開発を進めているコンポジットYb:YAGマイクロ チップのコア径と同サイズとした。照射ビームの強度プ ロファイルは中央にやや高いピークを有するがその周囲 はほぼフラットである，照射されるヒートシンクの表面 にはレーザー結晶は取り付けず, 熱源となるレーザー光 を効率よく吸収し，かつIRカメラで精度よく温度が測れ るように薬品を用いて表面を酸化させ薄く均一な黒色膜 を形成した。使用したIRカメラはNikon LAIRD-S270Aで Spectral rangeは3〜5 $\mu \mathrm{m}$ である.

Fig. 5に測定した各ヒートシンクの照射面のカメラの温 度イメージ像を示す．LDからの照射エネルギーは70 Wの 連続光 $(\mathrm{CW})$ で, 冷却水の水温は $20^{\circ} \mathrm{C}$ あ゙あ. 冷却水の流

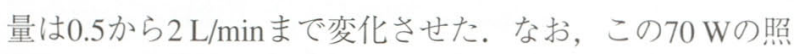
射による発熱は, 黒色膜での吸収率 $(0.78)$ を考えると実際 にYb:YAG結晶を接合した場合における $600 \mathrm{~W}$ の励起光吸 収時に相当する発熱量になる。この結果よりいずれの構 造のヒートシンクにおいても流量の増加と共に表面温度 が低下している様子がわかるが, 特に(c) (d)のマイクロ チャンネル構造のヒートシンク $(\mathrm{VFMH})$ においては少ない 流量から温度上昇が小さいことが分かる。また裏面がフ ラットな $(\mathrm{a})$ の $2 \mathrm{~L} / \mathrm{min}$ 時よりも, 流量の少ない $0.5 \mathrm{~L} / \mathrm{min}$ 時 のマイクロチャンネル構造のものの方が低い温度上昇を 示していることは特筆すべきである。また溝幅の異なる (c)と (d)ではそれほど大きな差は見られないが溝幅が小さ

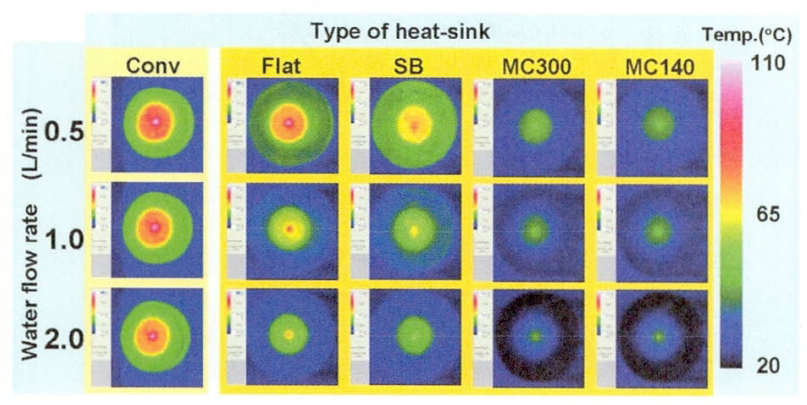

Fig. 5 IR camera images of the laser-irradiated heat-sinks as a function of water flow rate.
い方が温度上昇はより低く抑えられている。一方横水流

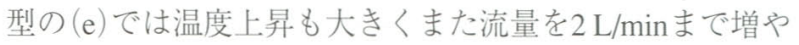
しても温度の低下の度合いは少ない. 従来型のヒートシ ンクの材料であるCuWはCuに比べ熱伝導率が $65 \%$ と小さ いが，この温度上昇の振る舞いは材料の熱伝導率の違い では説明できず，冷却構造そのものに大きな原因がある と考えられる。

Fig. 6はFig. 5の測定結果を流量に対する温度で示したグ ラフである。ビーム中央を除き強度プロファイルがほほ フラットになっている領域の温度を平均して示した。 結 晶取り付け面の裏側にマイクロチャンネル構造を形成す ることで, 結晶取り付け面の温度上昇をフラットのもの

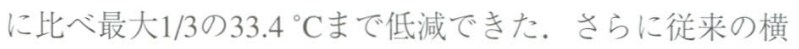
水流型に比べると $1 / 4$ 以下に抑えることが出来, 今回ヒー トシンクの小型化と同時に高排熱化も達成することがで きた. $\operatorname{VFMH}(\varnothing 5 \mathrm{~mm}$ 領域 $)$ の熱抵抗の值としては $140 \mu \mathrm{m}$ 間隔のマイクロチャンネルで $2 \mathrm{~L} / \mathrm{min}$ 時において $0.25^{\circ} \mathrm{C} / \mathrm{W}$ と求められる.

\section{4 有限要素法による冷却効率改善の見積もり}

実験結果より結晶取り付け面の裏面にマイクロチャン ネル構造を付与することにより冷却効率が改善され温度 上昇が大幅に抑えられることが分かった。 次に有限要素 法を用いてマイクロチャンネルの効果を理論的に解析し 実験結果と比較を行った。熱構造解析には市販の有限要 素法ソフト (ANSYS ED ver.7.016) ) を用いた. 本構造の熱解 析を行うにおいて最も不明なパラメータはヒートシンク と冷却水との界面での熱伝達係数である. 特に今回のよ うに噴流を吹き付ける構造で吹き付けられる表面に複雑 な構造を有する場合には計算だけで求めるのは容易でな く，また大きな䛊差を含む可能性がある。そこで今回， 熱伝達係数は実験結果と計算をフィッティングさせて見 積もりながら裹面形状の違いによる温度差の解析を進め た. Fig. 7 に具体的な解析形状の一例 ((d) MC140) を示す. マイクロチャンネルは同図のように理想的な矩形を仮定 し，その表面における水との熱伝達係数は凸部，凹部， その側面いずれも一様と仮定した。 与えた熱量(熱流量 $2.78 \mathrm{MW} / \mathrm{m}^{2}$ ) は実験におけるØ5 $\mathrm{mm}$ に $70 \mathrm{~W}$ のレーザー光 を照射した場合に酸化銅の放射率の文献值 $0.78^{17)}$ より $78 \%$ のエネルギーが表面で吸収されると想定したものである。

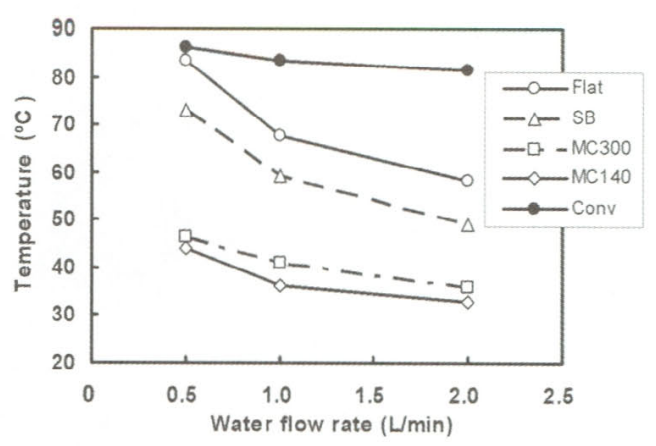

Fig. 6 Temperature of the laser-irradiated surface of the heat-sinks measured by an IR camera as a function of water flow rate. 


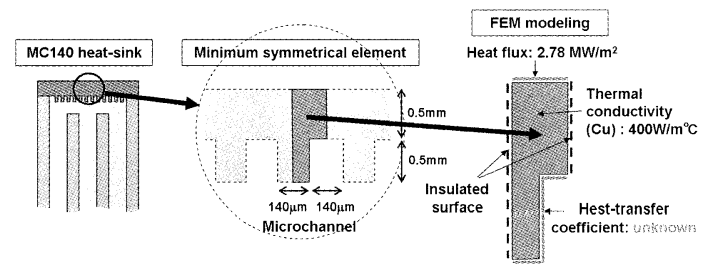

Fig. 7 Modeling of the finite element method for the MC140 structure.

Fig. 8は水とヒートシンク表面の間の熱伝達係数(横軸) をパラメータとし結晶取り付け面の温度上昇を計算した 結果である。裏面の形状としては凹凸がない (a) Flatと， (c)MC300，(d)MC140の2種類のマイクロチャンネル構造 (高さ (depth) $0.5 \mathrm{~mm}$ )を想定した. この図より熱伝達係数 が高くなるほど表面温度が下がること，またマイクロ チャンネル構造を設けることで, 表面における熱伝達係 数が同じでも放熱面積の増加により Flatに比べ半分以下に 温度上昇が低減できる様子が計算でも求められる。詳細 に見るとFig. 6の結果より Flatの温度は流量 $0.5 \mathrm{~L} / \mathrm{min}$ の時 83 ${ }^{\circ} \mathrm{C}$ と求められている。 これをFig. 8に当てはめると熱伝達 係数として $47 \mathrm{~kW} / \mathrm{m}^{2} \mathrm{~K}$ とう值が求められる．形状が大き く変化しなければ熱伝達係数はほぼ水の流量(流速)で決ま ると考えられるので，マイクロチャンネル構造における各 面の熱伝達係数もそれぞれの面はFlat と同じ熱伝達係数を有

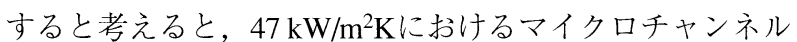
構造の温度上昇の計算值をFig. 8から求めることが出来る. 同様に $1 \mathrm{~L} / \mathrm{min}, 2 \mathrm{~L} / \mathrm{min}$ 時のFlatの温度上昇の測定值から熱 伝達伭数を求め, その值を代入してFig. 8からマイクロチャ ンネル構造の温度上昇の計算值を求めることが出来る.

Fig. 9はFig. 6の計測結果にFig. 8の計算により求めたマ イクロチャンネル構造の温度上昇を重ね書きしたもので ある．測定值と計算值の温度が非常に良く一致している ことが分かる。このことからマイクロチャンネル構造の 付加により表面積が増加しそれによって温度上昇を大幅 に低減できることが理解できた。また本構造における熱 伝達係数の流量に対する概算值も得ることが出来た.

Fig. 10は見積もられた熱伝達係数を用いて, さらに構造 パラメータとして横軸にマイクロチャンネルの溝の深さ を変えて, 結晶取り付け面の温度上昇を計算した結果で

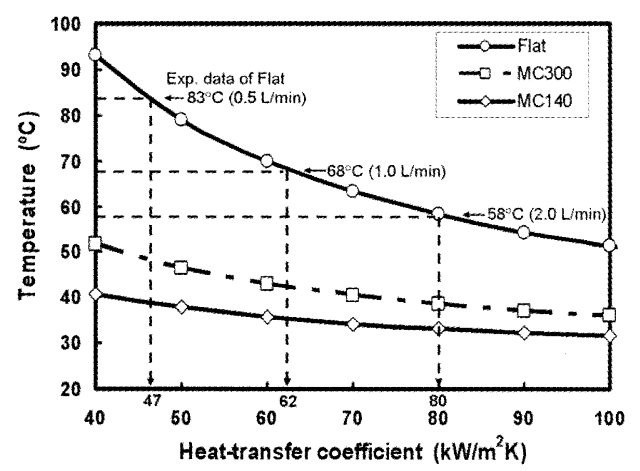

Fig. 8 Calculated temperature of the laser-irradiated surface of the heat-sinks by the finite element method (FEM) of ANSYS as a function of heat-transfer coefficient.

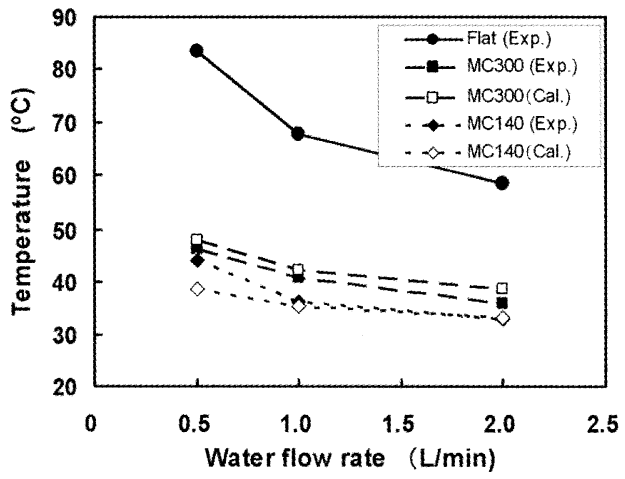

Fig. 9 Comparison of the temperatures of the laser-irradiated surface of the heat-sinks measured by an IR camera (Exp.) and calculated by FEM using the estimated heat-transfer coefficient (Cal.).

ある. Fig. 10の挿入図に解析形状を示す。マイクロチャン ネル表面の熱伝達係数としては流量がほぼ $1 \mathrm{~L} / \mathrm{min}$ 時に相 当する $60 \mathrm{~kW} / \mathrm{m}^{2} \mathrm{~K}$ とた。この計算ではさらにヒートシ ンクの材料として熱伝導率は劣るが線熱膨張係数がYAG に近い $\mathrm{CuW}(\mathrm{Cu} 30 \%)$ を用いた場合も検討している。な お，この計算では今後レーザー結晶取り付け面に段差加 工をすることを考慮し，ヒートシンクの上面(結晶取り付 け面)と裏側のマイクロチャンネル凹部(ない場合は平面 部)との距離(厚み) は $1 \mathrm{~mm}$ と厚く想定している。この図よ り熱伝導率の高い $\mathrm{Cu}$ の方が全域にわたり $5^{\circ} \mathrm{C}$ 程度温度が低 くなるが，いずれの材料においてもチャンネルの深さが $0.5 \mathrm{~mm}$ 超えると温度上昇はほぼ一定になっており，そ れ以上深く(長く)してもあまり改善は期待できないことが 分かる.これはマイクロチャンネルの凸部がヒートシン クより $0.5 \mathrm{~mm}$ 以上離れた領域では，放熱によってしだい に水温と温度差がなくなり，それ以上長くしても放熱効 果が飽和するためである。この計算結果よりマイクロ チャンネルの媣さは $0.5 \mathrm{~mm}$ でほぼ十分であることが分 かった、実際にチャンネルの高さが $1 \mathrm{~mm}$ のヒートシンク も試験的に製作し同様の温度上昇の測定を行った結果か らも, 高さ $0.5 \mathrm{~mm}$ ののに比べ温度上昇の改善は $2{ }^{\circ} \mathrm{C}$ 程度 と小さいことが確認された。この計算結果から, 先に実 験で示した従来型の横水流型マイクロチャンネルヒート シンク (e)においてはチャンネルの長さが10 mm以上ある ものの, そのほとんどの部分が冷却に寄与しておらず,

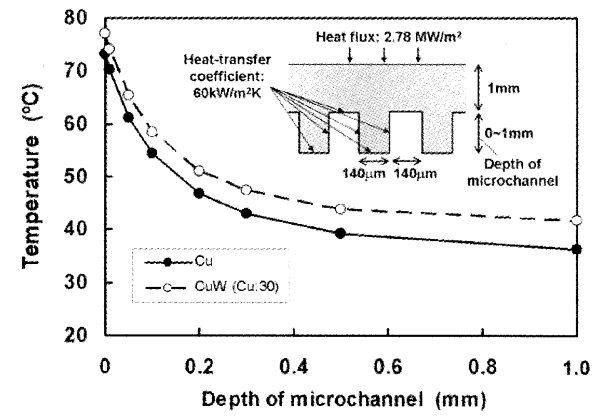

Fig. 10 Calculated temperature of the laser-irradiated surface of the heat-sinks by FEM as a function of the depth of the microchannel. 
逆に不要な水の割合(断面積)が多いために流速が遅く、こ のため熱伝達係数が低い值となり冷却効率が低くなった ものと理解できる。

\section{5 衝突噴流における熱伝達係数の見積もりについて の考察}

衝突噴流は比較的簡単な構成で高い熱・質量輸送効率 を得ることが出来るために，古くから注目され，また実 際に工業的にも金属やガラスの加熱・冷却・乾燥処理や エンジンの泠却などに適用されている。原理としては表 面に衝突した噴流はそこで減速して圧力が生じ，今度は 表面に沿った流れが加速される。噴流衝突直下のよどみ 領域 (stagnation region)では, 速度境界層や温度境界層の厚 みが数 $10 \mu \mathrm{m}$ のオーダーと極めて薄くなるために, 衝突表 面の近傍で非常に高い熱・質量輸送係数を得ることがで きる。前項では実験結果と有限要素法による計算結果と の比較よりヒートシンクと水との界面の熱伝達係数を見 積もつたが，噴流衝突冷却については学問的にもこれま で多くの実験・解析結果が発表されている。しかしなが ら形状や条件が多種多様で, 現象も非常に複雑でから実 験条件に敏感であるために結果のばらつきが大きい。ま た衝突面に凹凹を有するような実験解析例は非常に少な く18，特にVFMHの様に閉じた系では例がない，そこで衝 突面がフラットである実験解析結果を参照し, 熱伝達係 数の大きさを検討する。よどみ領域においてヌセルト数 は次式で表される19)。

$$
N u=h d / k
$$

ここでhは熱伝達係数, $d$ はノズル直径 $(2.6 \mathrm{~mm}), k$ は流 体 (水)の熱伝導率 $(0.6 \mathrm{~W} / \mathrm{mK})$ である。またヌセルト数は 一般にレイノルズ数Reとプランドル数 $\operatorname{Pr}(300 \mathrm{~K}$ 常圧の水の 場合5.85)の関数としても表され，今回の実験の場合Reは 流量 $1 \mathrm{~L} / \mathrm{min} て ゙$ よそ9500と計算される。さらにNuはdとノ ズル先端と衝突表面との距離 $z_{0}$ と比 $z_{0} / d$ も大きく変化す るが, 今回の場合 $z_{0}$ は $0.5 \sim 1 \mathrm{~mm}$ であるため $z_{0} / d<1$ となり $\mathrm{Nu}$ は $z_{0} / d$ に対して依存しない, ほぼ一定の值の領域にな る。この条件における $\mathrm{Nu}$ の值 (測定值) は複数の論文 ${ }^{18,19)}$ から約 200 (ばらつき $10 \%$ 程度) と求められるため，(1)式 から熱伝導率 $h$ として $46 \mathrm{~kW} / \mathrm{m}^{2} \mathrm{~K}$ と求められる. 今回の実 験でFig. 8 Flatから求めた值 $\left(62 \mathrm{~kW} / \mathrm{m}^{2} \mathrm{~K}\right)$ はこの文献值に 比べやや大きいが, 構造の違いや文献による測定值のば らつきなどを考えると, 衝突噴流構造における熱伝達係 数としては矛盾のない值であると考えられる.

\section{5. ヒートシンクヘのマイクロチップの実装と レーザー発振特性}

Fig. 11に今回開発したVFMHに実際にYb:YAGマイクロ チップを接合した外観写真を示す。マイクロチップはコ アとなる 5 at.\% 単結晶Yb:YAGロッド(Scientific Material) の周囲にアンドープのセラミックYAGを焼成により一体 化(コンポジット化)した後(神島化学工業製)，マイクロ チップに加工整形し，各面にそれぞれHR，ARコートを
行った後HR面側をヒートシンクにAu-Snハンダにより加 熱接合した。真円形の単結晶Yb:YAGコアは $\varnothing 5 \mathrm{~mm}$, 外側 の励起光ガイドとなるアンドープYAGセラミックの外形 は $8 \mathrm{~mm}$ 角, 厚みは $0.3 \mathrm{~mm}$ で, 4力所に励起光を導入するた めの直線ウィンドウ面(幅6 mm) 有する。

Fig. 12にFig. 11で示した結晶付きヒートシンクに励起を 行うために試作した 4 万向 $1 \mathrm{~kW}$ 励起モジュール(レーザー ヘッド)の外観写真を示す。使用した励起用LDはFA方向 コリーメートレンズ付き6段スタック型LD (JOLD-240CAFN-6A, JenaOptics) 最大単体出力 $240 \mathrm{~W}$ で, 集光光学ユ ニットは2枚のシリンドリカルレンズ，焦点距離それぞれ $30 \mathrm{~mm}$ (SA方向), $7 \mathrm{~mm}$ (FA方向) から構成される。これに よりLDからの励起光はマイクロチップの光ガイドウィン ドウ面内でおよそ高さ $0.1 \mathrm{~mm}$ (FA方向 $) \times$ 幅 $4 \mathrm{~mm}$ (SA方向 $)$ の矩形スポット $\left(1 / \mathrm{e}^{2}\right.$, 全幅)に集光され, 高効率で結晶内 に導入される。

次に試作したVFMHが，実際にレーザー結晶を装着した 状態で所望の冷却性能を発揮していることを確認するた めの検証を行った. Fig. 13は励起入力 $183 \mathrm{~W}(\mathrm{CW})$ 時の $\mathrm{Yb}$ : Y A G コア中心部の表面 (AR 面) 温度上昇をIRカメラ (Thermo-vision CPA-8000(CHINO), Spectral range: 7.5〜13 $\mu \mathrm{m})$ により計測した結果である。測定は非発振状態で行っ た。なお発振状態に拈いても温度上昇值はほぼ同等で

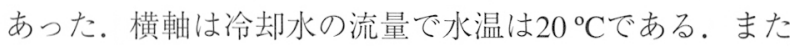
Fig. 8で見積もられた熱伝達係数を用いてYAG結晶上面の 温度上昇をANSYSでシミュレーションした結果も合わせ て示す。な拧シミュレーション結果中のエラーバーは励 起強度の見積もり誤差を反映したものである。理論計算

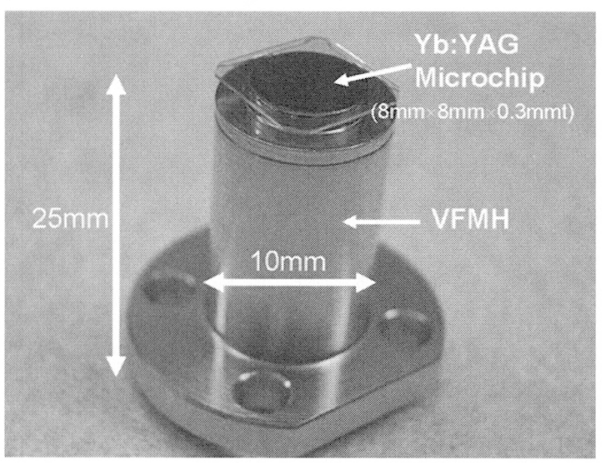

Fig. 11 Photography of the new heat-sink (VFMH) with a composite Yb:YAG microchip bonded on the top.

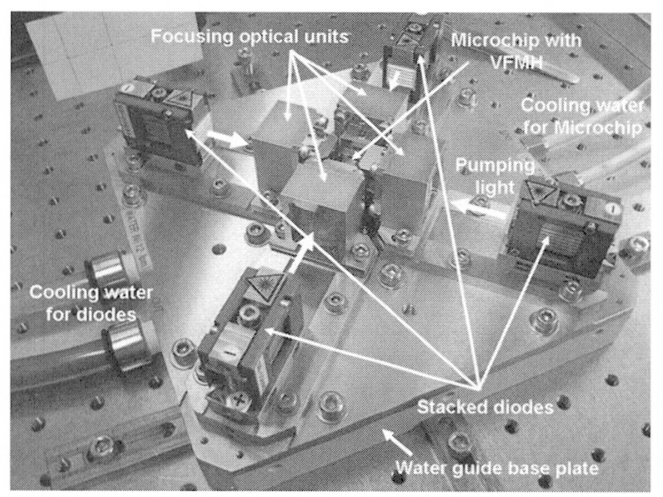

Fig. $121 \mathrm{~kW}$ diode edge-pumping module. レーザー研究 2006 年 2 月 


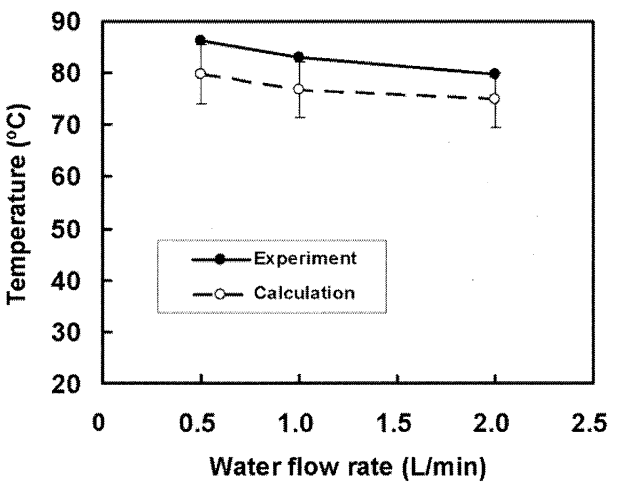

Fig. 13 Comparison of the measured and calculated temperatures of the AR coated surface of the Yb:YAG microchip core bonded on the VFMH as a function of water flow rate, edge-pumped by diode lasers (183W CW).

に比べ測定結果の方がやや温度が高いが良い一致が得ら れている。理論計算では結晶とヒートシンクの間の各層 の界面の熱伝達を理想的なものと考えているが，実際に は酸化層や変性層, 欠陥などにより途中に熱抵抗が生じ たために計算より温度が上昇した可能性がある。

Fig. 14にFig. 12の集光モジュールを用いて得られたレー ザー発振特性を示す. VFMHへの冷却水温度 $20{ }^{\circ} \mathrm{C}$, 流量 $2 \mathrm{~L} / \mathrm{min}$, レーザー共振器長 $50 \mathrm{~mm}$, 出力ミラーの曲率 250 $\mathrm{mm}$, 反射率 $97 \%$ において CW動作で $958 \mathrm{~W}$ 励起時に出力 $340 \mathrm{~W}$ (スロープ効率40\%, 光-光変換効率36\%) と良好な 高出力発振特性が得られ20), 新しいヒートシンク (VFMH) の高い冷却性能を確認することが出来た。なおこのVFMH に高熱伝導性接着剤を用いてマイクロチップを接着した 素子においても，同じ励起構成において $280 \mathrm{~W}$ 超える CW出力を確認している21).

\section{6. まとめ}

エッジ励起高出力マイクロチップYb:YAGレーザー用の ヒートシンクを開発した。冷却水を縦方向に吹き上げる 方式に変更することで四方から集光レンズを近接できる 外形 $\varnothing 10 \mathrm{~mm} \times$ 高さ $25 \mathrm{~mm}$ のスリムな構造を実現できた。

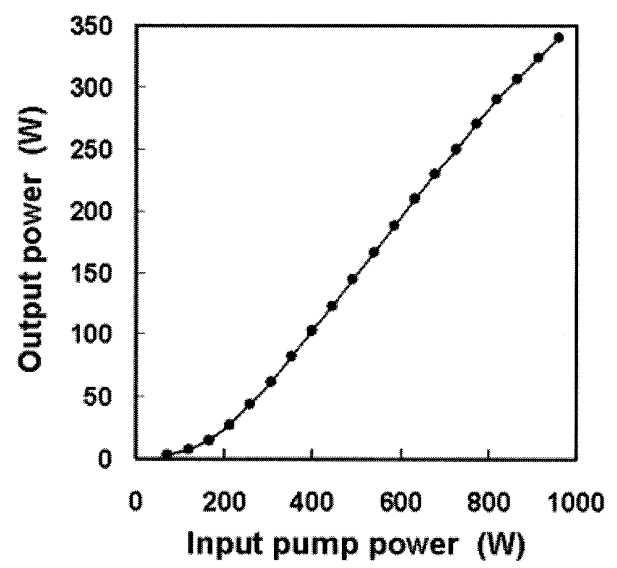

Fig. $14 \mathrm{CW}$ laser performance of the diode edge-pumped Yb:YAG microchip laser using the VFMH.
結晶取り付け面の裏側にマイクロチャンネル構造を形成 することで, 結晶取り付け面の温度上昇をフラットのも のに比べ最大 $1 / 3$ まで低減できた。 さらに従来の横水流型 に比べると $1 / 4$ 以下に抑えることが出来，ヒートシンクの 小型化と同時に高排熱化も達成することができた。また 有限要素法による理論計算によりこの効果が放熱面積の 拡大によるものであることが理解でき，さらにチャンネ ルの深さは $0.5 \mathrm{~mm}$ れば放熱効果として十分であること が分かった、製作したVFMHに実際にYb:YAGマイクロ チップを実装しLD励起を行うことで，CWレーザー出力 $340 \mathrm{~W}$ 得ることが出来た。このエッジ励起マイクロレー ザー発振特性の詳細については別途稿を改めて報告する。

謝 辞

ヒートシンクの製作を手伝って頂いた自然科学研究機 構分子科学研究所, 装置開発グループの鈴井班長, 矢野 技師に感謝する。また本地域結集型共同研究事業のアド バイザーとしてヒートシンク上面の超平面加工研磨に関 しご助言頂いた森 勇蔵，大阪大学名誉教授ならびに片岡 俊彦，大阪大学教授に感謝する。本研究により開発され たヒートシンクに取り付けたマイクロチップ固体レー ザー結晶は平成16年度の経済産業省の地域発コンソーシ アム事業に採択され, 福井県内の企業 ((株)ケイ・エス· ティー・ワールド)に拈いて製品化に向けた開発を現在進 めている.

\section{参考文献}

1) 庄司一郎，平等 拓範：光アライアンス 12 (2001) 19.

2) 平等 拓範, 常包正樹, ダスカル・トライアン：レーザー研 究33 (2005) 228.

3) P. Lacovara, H. K. Choi, C. A. Wang, R. L. Aggarwal, and T. Y. Fan: Opt. Lett. 16 (1991) 1089.

4) T. Y. Fan: IEEE J. Quantum Electron. 29 (1993) 1457.

5) E. Innerhofer, T. Sudmeyer, F. Brunner, R. Haring, A. Aschwanden, R. Paschotta, C. Honninger, M. Kumkar, and U. Keller: Opt. Lett. 28 (2003) 367.

6) J. Saikawa and T. Taira: Jpn. J. Appl. Phys. 42 (2003) L649.

7) T. Y. Fan: IEEE J. Quantum Electron. 28 (1992) 2692.

8) A. Giesen and F. Dausinger: レーザー研究 33 (2005) 219.

9) T. Kasamatsu, H. Sekita, and Y. Kuwano: Appl.Opt. 38 (1999) 5149.

10) N. Pavel, J. Saikawa, and T. Taira: Jpn. J. Appl. Phys. 40 (2001) 146.

11) T. Dascalu, T. Taira, and N. Pavel: Opt. Lett. 27 (2002) 1791.

12) T. Dascalu, N. Pavel, and T. Taira: Appl. Phys. Lett. 83 (2003) 4086.

13) U. Brauch, A. Giesen, A. Voss, and K. Wittig: US Pat. 5553088 (1996).

14）常包正樹，ダスカル・トライアン，平等拓範：レーザー学会 第25回年次大会予稿集 (2005年1月) p. 46 ; 常包 正樹，平等 拓範：特願2003-375057.

15）宮島 博文，古田 慎一，鈴木 英樹，大石 諭，森田 剛德，宮 本昌浩, 神崎武司, 管博文：レーザー学会第290回研究会 報告 RTM-01-36 (2001) p.29.

16) CAD/CAE委員会編：ANSYS工学解析入門(理工学社, 東京, 2003年).

17) 相原 利雄：伝熱工学(裳華房, 東京, 2004年).

18) D. Priedeman, V. Callahan, and B. W. Webb: J. Heat Transfer 116 (1994) 486.

19) B. W. Webb and C. -F. Ma: Adv. Heat Transfer 26 (1995) 105.

20) M. Tsunekane, T. Dascalu, and T. Taira: Techical Digest of Conf. on Lasers and Electro-Optics. Baltimore, May 2005, CTuZ3 [invited].

21) M. Tsunekane and T. Taira: Jpn. J. Appl. Phys. 44 (2005) L1164. 